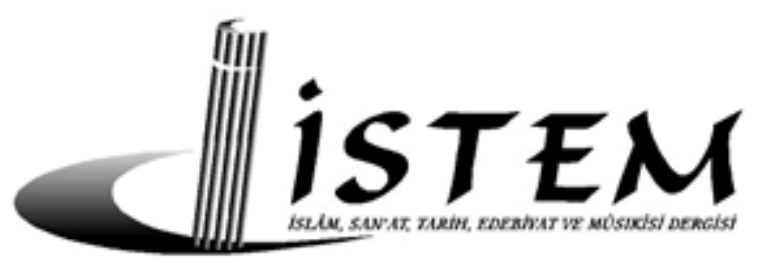

yıl / year: 17 • sayı / issue: 33 • yaz / summer 2019•s./p. $65-87$

\title{
Diyanet İşleri Başkanı Eyüp Sabri Hayırlıoğlu ile Yaşanan Latince Kur'an Polemiği
}

\author{
MAHMUT ÖZTÜRK \\ Doç.Dr., Harran Üniversitesi İlahiyat Fakültesi Öğretim Üyesi \\ İslam Tarihi Anabilim Dalı \\ Geliş Tarihi / Received: 26.03.2019 • Yayına Kabul Tarihi / Accepted: 23.05.2019
}

\section{Atıf/ Cite as}

Öztürk, Mahmut. “Diyanet İşleri Başkanı Eyüp Sabri Hayırlıŏlu ile Yaşanan Latince Kur’an Polemiği”. İstem, 17/33 (2019): 65-87. https://doi.org/10.31591/istem.545003

\section{Öz}

Eyüp Sabri Hayırlıoğlu, Türkiye Cumhuriyeti'nin 4. Diyanet İşleri Başkanıdır. (17.04.195110.06.1960 tarihleri arası) Onun başkanlık süresi, Demokrat Parti'nin iktidarda olduğu dönemlere denk gelmektedir. Hayırlığlu, başkanlığı döneminde görev alanına giren bazı konularda basın mensuplarıyla tartışmalar yaşamıştır. Hayırlığlu'nun basınla yaşadığı polemik konularından birisi de Latince Kur'an meselesidir. Hayırlığlu, kendisine sorulan bir soruya cevaben Kur'an'ın Latin harfleriyle yazılmasına cevaz vermeyince, bazı basın organları ve derneklerin hedefi olmuştur. Bilim adamları, dernekler, basın organları ve halk olaya müdahil olmuş, tartışmalar uzun süre devam etmiştir. Latince Kur'an'a taraftar olanlar, Latince Kur'an'ın bir intiyaç olduğunu, Atatürk inkılaplarının Latince Kur'an'ı gerektirdiğini, transkripsiyon alfabesinin Latince Kur'an için yeterli olduğunu ileri sürmüşlerdir. Hayırlığlu ve ona destek çıkanlar ise Latince Kur'an isteyenlerin bu taleplerinde samimi olmadığını, transkripsiyon alfabesinin çözüm için yeterli olmayacağını, Kur'an-ı Kerim'in resm-i hattını değiştirmenin caiz olmadığını iddia etmişlerdir. Hayırlıoğlu, siyasi iradenin de desteği ile kararında geri adım atmamış, emekli oluncaya kadar Latince Kur'an konusuna geçit vermemiştir.

Anahtar Kelimeler: Eyüp Sabri Hayırlıoğlu, Latince Kur'an, Sebilürreşad, Milliyet Gazetesi, Cumhuriyet Gazetesi

\begin{abstract}
The Polemic On The Latinization of Quran With The Fourth President Of Religious Affairs Eyyup Sabri Hayirlioğlu

Eyüp Sabri Hayırlıoğlu is the 4th President of Religious Affairs of Turkey (Between17.04.1951 and 10.06.1960). His presidential term coincides with the period when the Democratic Party was in power. During his presidency he argued with members of the press about some issues related to his area of responsibility. One of these polemical topics is the latinization of Quran. Upon not giving permission to latinization of Quran in response to a question adressed to him, he became the target of some press organs and associations. Scientists, associations, press organs and the public got involved in the debates, and the debates continued for a long time. The supporters of latinized Quran argued that rewriting Quran in latin alphabet is a necessity, Ataturk's reforms require this and that the transcription alphabet is sufficient for reciting latini-
\end{abstract}


zed Quran. Hayırlığlu and the ones who supported him claimed that those who want latinized Quran aren't sincere in their requests, that it's not permissible to change the official calligraphy of Quran and the transcription alphabet would not be sufficient for the solution. With the support of political will, he didn't step back from his decision and didn't give a permission to latinize Quran until he retired.

Keywords: Eyüp Sabri Hayırlığlu, Latin Koran, Sebilürresad, Milliyet Newspaper, Cumhuriyet Newspaper.

\section{Giriş}

Türkiye Cumhuriyeti'nin kuruluş arifesinde daha devletin adı bile konulmadan yeni ile eski arasındaki irtibatın mahiyeti tartışmaya açılmıştır. Şu bir gerçektir ki Kurtuluş Savaşı'nda ciddi şekilde batılılaşma taraftarı olanlarla, sistemin kusurlu taraflarını ıslah ederek mevcudu korumayı isteyenler yan yana mücadele etmiştir. Ancak harici tehlike karşısında muvakkaten gündemden kaldırılan intilaflı konular, savaş sonrasında yeniden ve daha yüksek tonda dillendirilmiştir. Çok ciddi sonuçlar doğuracak tartışma konularından birisi de yola Arap alfabesi ile mi, yoksa Latin alfabesi ile mi devam edileceği meselesidir. Altı yüzyıllık geçmişi olan bir devlet için böyle bir tercihin sıradan bir harf değişikliğinin çok ötesinde sonuçlar doğuracağı gayet açıktır.

Tarihi süreç Latin alfabesi ile yola devam edildiğini göstermektedir. Fakat bu alfabe tercihi beklendiği gibi hızını kesmemiş, çeyrek asır sonra Latin alfabesinin başta Kur'an-ı Kerim olmak üzere Arap alfabeli dini metinlere de uygulanması gündeme getirilmiş, bu konuda ciddi tartışmalar ve polemikler yaşanmıştır. Latince Kur'an'a taraftar olanlar, İslamiyet'in yayılması için bunun bir ihtiyaç olduğunu ileri sürerek düşüncelerini Atatürk İnkılaplarıyla gerekçelendirmeye çalışırken, karşı çıkanlar onları samimiyetsizlikle itham edip konunun inkılaplarla alakası olmadığını, Latin harflerle Kur'an yazmanın ilmi olarak imkânsız olduğunu ileri sürmüşlerdir. Uzun süre tartışılan konunun akisleri yurtdışında da hissedilmiştir.

\section{Latince Kur'an tartışmalarının seyri}

“Latince Kur'an"1 1958 yılı ortalarında ortaya çıkmış yeni bir mesele gibi görünse de bunun fikri alt yapısının yarım asırlık bir geçmişe dayandığını söylemek mümkündür. Latin harflerinin kabulünden kısa süre önce Abdullah Cevdet, (ö. 1932) İctihad dergisinde yayımlanan bir makalesinde medeni aileler arasına katılmak için şarktan ayrılmak ve Arap harflerini terk edip yerine Latin harflerinin kullanmak gerektiğini savunmuş, bir gün bunun mutlaka gerçekle-

\footnotetext{
${ }^{1}$ Yazı boyunca “Latince Kur'an” ifadesiyle Latin harfleriyle yazılmış, Arapça ifadeli Kur’an kastedilecektir.
} 
şeceğini iddia etmiştir. ${ }^{2}$ Kazım Karabekir (ö.1948) gibi devlet adamları bunun ayak seslerini çok önceden fark edip buna engel olmak istemiş ancak muvaffak olamamışlardır. ${ }^{3}$ Cumhuriyetin ilanından yaklaşık beş yıl sonra, 1 Kasım 1928'de Latin harfleri resmen kabul edilmiştir.

Yurt dışındaki Türklerde alfabe dönüşümü bu kadar hızlı/keskin olmamış, Batı Trakya'daki bazı basın organları bir süre daha Arap alfabesiyle neşriyata devam etmişlerdir. Öyle anlaşılıyor ki bu tercih sadece bir alfabe farkılı̆̆ı olarak kalmamıştır. Basına yansıyan haberlerden 1950'li yolların sonlarına doğru Batı Trakya'da yaşamakta olan Müslümanlar arasında çeşitli konularda fikir ayrılıkları yaşandığı anlaşılmaktadır. Bu ayrılıklalar Türkiye'deki basın organlarına da yansımıştır. Cumhuriyet ve Milliyet gibi gazeteler, Batı Trakya'daki gelenekten yana olan muhafazakâr grubu mürteci olarak yaftalarken, onlara karşı olanları devrimci nitelemesiyle alkışlamıştır. Sebilürreşad ve Batı Trakya'da yayınlanmakta olan Sebat gazetesi ve bu çizgide olan basın organları ise tersi istikamette bir yayın politikası izlemişlerdir.

Batı Trakya'daki bu gruplar arasında Kur'an'ın Latin harfleriyle yazılıp yazılamayacağı meselesi ciddi olarak tartışılırken konuyu Türkiye'deki en yüksek dini makama arz etmeye karar veren Batı Trakya Türklerinden öğretmen Mustafa Kafalı ${ }^{4}$ Diyanet İşleri Başkanlığı'na bir mektup yazarak konu hakkındaki görüşlerini sormuş, bir anlamda fetva istemiştir. Diyanet İşleri Reisi Eyüp Sabri Hayırlığlu bir din adamı nezaketiyle ve iyi niyetlerle 1 Haziran 1958 tarihinde $^{5}$ ona cevap yazmış, gerekçelerini de sıralayarak Kur'an'ı Latin harflerle yazmanın caiz olmayacağını bildirmiştir. Mektup Hayırlığlu'nun izni ve haberi olmaksızın Yunanistan'da Arap harfleriyle basılmakta olan Sebat gazetesinde yayınlanınca, tabiri caizse kızılca kıyamet kopmuştur. ${ }^{6}$ Hayırlıoğlu gibi düşünen Gümülcine Müftüsü ile Batı Trakya Türk Cemaati Reisi Selahattin Galip arasında sert tartışmalar cereyan etmiştir. Milliyet Gazetesinin haberine göre Batı Trak-

\footnotetext{
2 Abdullah Cevdet [Karlıdağ], “Latin Harfleri Meselesi” ictihad Dergisi 23/240 (15 Teşrin-i evvel 1927): 4583-4586.

3 Eşref Edib, “Latin Hurufatı Aleyhinde Mühim Bir Rapor” Sebilü'r-Reşad 13/ 627 (27 Teşrin-i Sani 1340): 45.

${ }^{4}$ Bu şahıs hakkında farklı isimler zikredilmiştir. Avukat Ziya Nur'un yazısında bu isim Gümülcineli öğretmen H. Mustafa olarak geçer. Ziya Nur , “Gayeli Taarruz” Türkçe Kur'an Okunamaz, Haz. Mü'min Çevik, (İstanbul: Sinan Matbaası, 1958), 50, Milliyet Gazetesi, diyanete mektup yazan kişinin Mustafa Kafalı değil; onun kardeşi Bahattin Karagözoğlu olduğunu, Sebat gazetesinin mektubu yayınlarken isimde tahrifat yaptığını iddia etmektedir. Milliyet Gazetesi, 12.10.1958, s. 5.

${ }^{5}$ Nur, "Gayeli Taarruz", 50.

6 “Diyanet Reisinin Beyanatı” Sebilürreşad, 12/297 (Kasım 1959): 50.
} 
ya'da mürtecilerle devrimciler arasında eskiden beri sessiz bir şekilde devam etmekte olan çekişme Latince Kur'an meselesi ile tekrar alevlenmiştir. ${ }^{7}$ Tartışmalar suya atılan bir taş gibi basını, bilim adamlarını, dernekleri ve halkı içine almış, taraflar kendi düşüncelerini çeşitli mahfillerde açıklama gayretine girişmişlerdir.

Kamuoyunda Hayırlıoğlu'ndan konuya ilişkin bir açıklama beklentisi olmuş, o da şahsi bir mektup etrafında cereyan eden bu hadise konusunda basına yazılı bir açıklama yapmayı uygun görmüştür. İnanmış olduğu davalarda daima büyük bir cesaret gösteren, hiçbir suretle dinin esaslarından ayrılmayan Hayırıığlu, düşüncelerinde geri adım atmayacağını net bir dille ifade etmiştir. ${ }^{8} \mathrm{Hayır-}$ Iıoğlu isim vermeden kendisini eleştirenlere cevap vermiş, açıklamasını daha çok ilmi temellere dayandırmaya çalışmıştır. Bu açıklamada öne çıkan hususlar özetle şöyledir:

1. Arapçanın ses ve gramer yapısı Kur'an-ı Kerim'in Arap alfabesi dışında bir alfabeyle yazılmasına imkân vermez. Arap alfabesinde bulunan 11 farklı ses Türk Alfabesinde mevcut değildir. Maarif kütüphanesi tarafından Latin harfleriyle bastırılan Kur'an-ı Kerim hatalarla doludur. Arapçadaki tesniye ve cemilerdeki uzatmaların çoğu müfret olarak seslendirildiğinden yapılan bu iş tahriften farksız değildir.

2. Türkçe alfabeye bazı karakterlerin ilavesi ile problemi çözmek de çare olamaz. Böyle bir uygulama, telaffuz açısından ek bir tedrisatı gerektireceğinden, işi kolaylaştırmış olmayacaktır. Orta ve yüksek tahsil gençliği Arap alfabesini çok rahat bir şekilde öğrenebilir.

3. Latin harfleriyle Kur'an-ı Kerim'i okumada ısrar edenler, yanlış okumayı peşinen kabul etmiş olmak koşuluyla piyasada mevcut olan Latin Harfli Kur'an-ı Kerim'leri okumakta özgürdürler.

4. Kur'an-ı Kerim'in Latin harfleriyle yazılması meselesinin Atatürk inkılaplarıyla hiçbir ilgisi yoktur. 1932 senesinde bir sure Latin Harfleriyle Yazılıp Atatürk'e takdim edilmiş, Atatürk bu uygulamaya sıcak bakmamış, 26/5/1932 tarih ve 6/1446 sayılı yazılı ve acil kayıtı emirle bir soruşturma başlatmıştır. Müşavere heyeti Kur'an-ı Kerim'i Latin harfleriyle basmanın onu tahrif etmek an-

\footnotetext{
${ }^{7}$ Milliyet Gazetesi, 13.10.1958, 3.

8 Ertan, Veli, “Sâbık Diyanet İşleri Başkanı Eyüp Sabri Hayırlığlu (1884-1960)", Diyanet İmi Dergi [Diyanet İşleri Başkanlığı Dergisi], $7 / 77$ (Ekim1968), 227-228.
} 
lamına geleceğini belirten görüşünü kendilerine ulaştırmıştır. Cumhuriyet Gazetesi ise Hayırlığlu'nun bu vesikalarına karşılık, 23 Ağustos 1928 tarihinde Tekirdağ'a yaptığı bir gezide Mevlana Hafız Mustafa Efendi adında bir kişi ile yaptığı sohbet esnasında konunun yeni harflere geldiğini, Atatürk'ün orada Tin suresinin ilk ayetlerini Latin harfleriyle yazıp bu şahsa verdiğini ve ondan Latin harflerini öğrenmesini istediğini belirten bir haberi “Inkılapların banisi Ata, Hayırlıoğlu'nun karşısına dikiliyor" manşeti ile vermiştir. ${ }^{9}$

Muhalif gazeteler, uzun süredir bekledikleri Hayırlıoğlu'nun basın açıklamasındaki izahlardan ziyade toplantının yapılış şeklini eleştiren haberler yapmışlardır. Hayırlıoğlu bir gün evvel gazeteleri aratarak, sorularını talep ettiği ve açıklamayı yazılı olarak yapacağını belirttiği halde, basın organları, onu soruları cevapsız ve toplantıyı yarım bırakmakla suçlamıştır. Toplantıdan sorumlu memuru "diyanetin kapıcısı" diyerek aşağılamaya çalışan gazeteler, oradaki bazı kişilerin de gazetecilerin adreslerini tespit etmeye çalıştıklarını ifade ile konuyu başka taraflara çekmeye teşebbüs etmişlerdir.

Basın organları tartışmada açıkça taraf olmuş kendileri gibi düşünen bilim adamı ve derneklerin görüşenlerini öne çıkarmışlardır. Milliyet Gazetesi Latin harfleriyle Kur'an'ın yazılabileceğini ifade eden görüşleri öne çıkarırken, Sebilürreşad bunun mümkün olmadığını dile getiren yazılar yayınlamıştır. Latin harfleriyle Kur'an'ın yazılması tartışmalarında bir günlük gazete konu hakkında açık uçlu bir anket düzenleyerek bu konuda okurların görüşlerini sormuş, bunun üzerine çok sayıda görüş bildirilmiştir. İlahiyat Fakültesi Öğretim üyeleri, bazı diyanet mensupları, köşe yazarları, konuya ilgi duyan diğer kalem ehli makaleler yazarak görüşlerini kamuoyu ile paylaşmışlardır.

Konuyu hararetli biçimde tartışanlardan birisi de dernekler olmuştur. Türkiye Milli Talebe Federasyonu, Trakya Türk Cemaati, Türk Devrim Ocakları, Mustafa Kemal Derneği ve Hür Fikirleri Yayma Cemiyeti, Latince Kur'an taraftarlarının ön saflarında tartışmaya katılmışlardır. Bu arada en kaba ve nezaketsiz eleştiriler Mustafa Kemal Derneği başkanı Muhtar Kumral'dan gelmiştir. “Cübbeni topla evine dön. Hiç durma, istifa et, istifa et, istifa et." diye tamamladığı açıklamasında neredeyse ilmi hiçbir cümle kullanmamış, konuşmasını baştan sona hakaret üzerine bina etmiştir.

\footnotetext{
${ }^{9}$ Cumhuriyet Gazetesi, 05.10.1958, 1.
} 
Cumhuriyet gazetesi Diyanet İşleri Başkanı Hayırlığlu'nun oğlu, sayın Orhan Hayırlıoğlu'na Latince Kur'an hakkındaki fikrini sorduğunda, o, bunun bir intisas işi olduğunu ifade etmiş, kendi görüşü olsa bile bunun duygusal nedenlere bağlanacağı endişesiyle susmayı tercih etmiş, bu tartışmalardan ziyade muhtasar bir Türkçe tefsire olan intiyacı gündeme getirmiştir. Ancak Mustafa Kemal Derneği başkanına, Diyanet İşleri Reisi hakkında söylediklerini ona hiç yakıştıramadığını, kendisinin onlardan ziyade inkılap nesli olduğunu, inkılapların değerini gençlerden daha iyi bildiğini sözlerine eklemiştir. ${ }^{10}$

Hayırlığlu'na hakaret etme hakkını kendilerinde bulan dernekler, Hayırlıoğlu'nun, istifasını isteyen üniversite öğrencilerinden "3-5 çocuk" diye bahsedilmesini sindiremeyerek kendilerinden özür dilemesini isteyebilmişleridir. TMTF ikinci başkanı Erol Ünal, Hayırlığlu'nun hala görevi başında kalmasının sabrı taşırdığını, kendi rızasıyla istifa etmeyeceğinin anlaşıldığını, ilgili makamların onu görevden almasını beklediklerini söylemiştir. ${ }^{11}$ Bu süre zarfında Hayırıığlu hemen her vesile ile yıpratılmaya çalışılmıştır. Görevinde iki yılı henüz geride bırakmışken görevden alınacağına dair haberler yıllarca devam etmiş, Latince Kur'an tartışmalarıyla beraber tekrar gündeme getirilmiştir. ${ }^{12}$ Yerine kimlerin tayin edileceğine kadar kehanetlerde bulunulmuş, ama hiç biri gerçekleşmemiştir. ${ }^{13}$

Cumhuriyet ve Milliyet gazetelerinin başını çektiği basın organlarının HayırIıoğlu'na hakarete varan eleştirilere sansürsüz yer vermesi, açtıkları psikolojik savaş ve kasıtlı yanlış bilgilendirme türü haberleri ve derneklerin Hayırlıoğlu'na fütursuzca saldırıları, muhafazakâr insanları gayrete getirmiş, Türkiye'nin her tarafından Hayırlıoğlu'na destek telgrafları çekilmiştir. Malatya, Manisa, Kütahya ve Trabzon gibi illerden gelen telgrafların çoğunlukla şahsi olmadıkları, yüzlerce, hatta on binlerce kişiyi temsilen kaleme alındıkları belirtilmiştir. Bazıları doğrudan Hayırlıoğlu'na bazıları da başbakan Adnan Menderes'e hitaben yazılmıştır. Menderes'e yazılan telgraflarda kendisinden “Allah'tan sonra güvenimiz”, “islam'ın kal'ası” şeklinde söz edilmesi dikkat çekicidir. Sebilürreşad'da yer alan bazı telgraflar ise "Mason Gazeteler" olarak nitelendirilen gazeteler ile

\footnotetext{
10 Cumhuriyet Gazetesi, 09.10.1958, 5.

11 Milliyet Gazetesi, 07.10.1958, 1.

12 Milliyet Gazetesi, 16.08.1953, 1.

${ }^{13}$ Milliyet Gazetesi, 09.10.1958, 1.
} 
Atatürk Derneği Başkanlığı'na hitaben kaleme alınmıştır. ${ }^{14}$ Bunların bir kısmı hakaret içermese bile duygusal yanı ağır basan telgraflar olduğundan aralarından bir ilim adamının Raif Cilasun'un yazdığı telgrafı örnek alarak buraya kaydetmek istiyoruz. Sebilürreşad gazetesi yazı işleri müdürlüğüne gönderdiği yazıda Latince Kur'an meselesinin ilmi bir mesel olduğunu tartışmanın ilim ehlince yapılması gerektiğini belirtir. Bunun dışındaki konuşmaların şarlatanlıktan öteye geçmeyeceğini belirtir. Yazısının sonunda Diyanet İşleri Riyasetine örneğini aşağıda vereceği telgraf gibi pek çok telgraf geldiğini belirterek onların bir özeti sayılabilecek bir metne yer verir. Bilgi notu ile telgraf mesajı arasındaki üslup benzerliğinden ikisinin de Raif Cilasun'un kaleminden çıktığına dair oluşan kanaatimizi belirterek ilgili metni sunuyoruz:

\section{Muhterem Diyanet İşleri Reisliği Yüksek Makamına}

İlahi vazifenize müdahaleye kalkan bazı küstahların yaygaraları sizi asla mahzun etmesin. Müslümanlar, Müslüman hukukuna siyanet edenlerin arkasındadır. Kur'an-ı Azimüşşan'ınen ufak tahrif şüphesi üzerinde göstereceğiniz kesin alaka ve hassasiyet vazifenizin iktizasıdır. Dini bilgi ve ihtisaslardan uzak ve tamamen kötü maksatlara dayandığını sandığımız bu mugalataların, masum vatandaşlarımız üzerinde indas etmek isteyecekleri bozgunluk, her iman sahibinin nefretiyle karşılanmaktadır. Allah'ın laneti ancak maneviyatı yıkan kötü hedeflere racidir. İlahi vazifenize dayanarak verdiğiniz karar, Kur'an-ı Kerim'in hukukuna müstenittir. Siz Müslümanların manevi hukukunu, ancak Kur'an-ı Kerim'in ve Ehadis-i Peygamberî'nin çizdiği hat ve kanun çerçevesinde görmek mecburiyetindesiniz. Sizi o makam-ı aliye getirenler, aynı temiz duygularla meşbu hükumetimizdir. Bugün ölü ve diri Türk'ün ilahi maneviyatı sizi tebrik ve hürmetle selamlar.

Allah'ta afiyetinizi ve bulunduğunuz makamı kudsiyette hulusla vazifenizde daim olmanızı temenni eder, ellerinizden hürmet ve muhabbetle öperiz. ${ }^{15}$

Hayırlığlu kendisine yapılan hakaretlere misliyle cevap vermek yerine hakkını mahkemelerde aramıştır. Kendisine yapılan hakaret sahiplerini (Muhtar Kumral, Şemsettin Günaltan, Osman Nebioğlu) mahkemeye vermiştir. Mahkemenin takipsizlik kararına itiraz ederek hakkını aramayı sürdürmüştür. ${ }^{16}$ Bazen

\footnotetext{
14 Sebilürreşad, 12/ 297 (Kasım 1959): 56-57.

15 Sebilürreşad, 12297 (Kasım 1959): 56-57.

16 Cumhuriyet Gazetesi, 15 Ocak, 1959, 1, 3.
} 
de Yeni İstanbul gazetesi Sahibi Edip Törehan ve Yazı işleri Müdürü Yılmaz Poda örneklerinde olduğu gibi mahkemeye başvursa da ${ }^{17}$ bilahare dava dilekçesini geri çekmiştir. ${ }^{18}$

Hayırlıoğlu, kendisine ve kurumuna yöneltilen bütün eleştirilere göğüs germiş, lüzumunda basına açıklamalarda bulunmuş ama Latince Kur'an konusunda bir adım olsun geri almamış, "Ben ahiretimi yakamam"19 diyerek meselenin ne kadar mühim olduğunu her defasında dile getirmiştir.

Hayırlıoğlu 17.04.1951-10.06.1960 yılları arasında zorlu bir hizmet döneminin sonunda sağlık deniyle emekliye ayrılmıştır. Onun istifa etmesi veya görevden ayrılması için elinden geleni yapan Milliyet Gazetesi emekliye sevk edilmesini 12.06.1960 tarihli nüshasında beş satırlık küçücük bir haberle duyurmuştur. "Diyanet İşleri Reisi Eyüp Sabri Hayırlıoğlu, emekliye sevk edilmiş ve onun yerine İstanbul Müftüsü Ömer Nasuhi Bilmen tayin olunmuştur." Elbette bu Milliyet ve Cumhuriyet gibi muhalif gazetelerin beklediği bir netice değildir.

Latince Kur'an meselesini ana hatlarıla bu şekilde özetledikten sonra şimdi de tarafların -ileri dürdükleri delil ve gerekçeler eşliğinde- görüşlerine yer vermek işitiyoruz.

\section{Latince Kur'an'a taraftar olanların gerekçeleri}

\subsection{Latince Kur'an'ın bir ihtiyaç olarak görülmesi}

Latince Kur'an taraftarları, bunun bir intiyaç olduğunu söylemişlerdir. İslamiyet'in yayııması, insanların dinini doğru öğrenmesi, başkaları tarafından aldatılmaması için Kur'an'ın yeni Türk alfabesiyle basılması gerektiğini dile getirmişlerdir.

Bern Büyük Elçisi Gökay, Kur'an-ı Kerim Arap diliyle peygambere nazil olsa bile Arap dilinin başka bir alfabeyle yazılmasına mani bir engel olmadığını, bu yüzden de gençliğin Arap dilini ve Arap harfleri öğrenmesine gerek olmadığını söylemiştir. Ona göre "Kur'an yeni harflerle yazılmasın” demek milyonlarca Türk Müslümanı Allah'ın kelamından mahrum bırakmak manevi hayatın doyulmaz faziletinden ve gıdasından uzak bulundurmak demektir. İslamiyet'in yayılması ve çocuklarımızın dinin manevi varlığı içinde yetiştirilmesi için Kur'an'ın Türkçe harflerle yazılmasını istemek hepimiz için bir vazifedir."20

\footnotetext{
17 Milliyet Gazetesi, 19.02.1959.

18 Milliyet Gazetesi, 17.12.1959, 1.

${ }^{19}$ Milliyet Gazetesi, 09.10.1958, 1.

20 Cumhuriyet Gazetesi, 20.10.1958, 1,3.
} 
Basında yer alan bazı demeçler işi Latince Kur’an' karşı çıkmayı büyük günahlar arasında zikretmeye kadar vardırmışlardır. Cumhuriyet Gazetesi böyle bir düşünceyi yurt dışından bulup ithal etmeyi başarmıştır. Habere göre dört ayrı üniversiten mezun olan, İmam Efendi adındaki Fin Türklerinin dini lideri şöyle demiştir: “Bu düşünce ile ben daha ziyade Kur'an'ı Türkçe yazmayıp okunmasının günah olacağını düşünürüm. Esasen Kur'an'ın da Arapça olarak ele alınıp yazılmadığını düşünürsek bunun doğruluğuna hepimiz inanırız." ${ }^{21}$ Bu düşüncenin elle tutulur bir tarafı olmadığı açıktır. Bu söz, müsteşriklerin Hz. Peygamber zamanında Kur'an'ın yazı ile tespit edilmediği şeklindeki iddialarının kötü bir tekrarından ibarettir.

MTTB genel sekreteri, Hayırlığlu'nun Kur'an'ın Latince alfabeyle yazılamayacağına dair fetvasıyla, Türk neslini, mensup olmakla bahtiyar olduğu, aziz ve büyük dinimizin imkânlarından tamamen ve ebediyen mahrum etmek istediğini iddia etmiştir. ${ }^{22}$ Havadis gazetesinin başyazısında Hayırlıoğlu'nun mektupla verdiği fetvanın, İslam dininin daha çok yayılmasını ve mukaddes kitabımızın daha geniş kitleler tarafından benimsenmesini can-ı gönülden arzu edenler arasında derin bir teessürle karşılandığı dile getirilmiştir. ${ }^{23}$

Araştırmalarımız boyunca Latince Kur'an'la beklenen faydaların nasıl temin edileceğine dair bir tek satırlık açıklamaya rastlamadığımızı belirtmek isteriz. Aynı şekilde Mushaf'ın asli haliyle neşrinin İslamiyet'in yayılmasına nasıl engel olduğu/olacağı açığa kavuşturulmamış, bütün bunlar dayanaksız birer iddia olarak ileri sürülmüştür.

\subsection{Atatürk İnkılaplarının Latince Kur'an'ı gerektirdiği iddiası}

Latin harfleriyle Kur'an'ın yazılmasına taraftar olanların demeçlerinde değindikleri konulardan birisi mutlaka Atatürk ve inkılaplar olmuştur. Latince Kur'an'ı harf inkılabının zorunlu bir uygulaması olarak görenler her fırsatta Atatürk ve İnkılapların arkasında mevzilenerek konuşmuşlardır. İlahiyat Profesörü Nazif Danışman, Kur'an-ı Kerim'in mutlaka eski harflerle okuma arzusunu, harf inkılabının bütün mana ve özelliklerini inkâr olarak görürken ${ }^{24}$ Batı Trakya Türk Cemaati Reisi Selahattin Galip basına verdiği demeçte Latince Kur'an'a karşı çıkmayı Cumhuriyet, Atatürk ve İnkılaplara karşı mücadele olarak lanse etmeye

\footnotetext{
${ }^{21}$ Cumhuriyet Gazetesi, 08.10.1958, 5.

22 Cumhuriyet Gazetesi, 08.10.1958, 5.

${ }^{23}$ Cumhuriyet Gazetesi, 5.10.1958, 5.

${ }^{24}$ Cumhuriyet Gazetesi, 5.10.1958, 5.
} 
çalışmıştır. ${ }^{25}$ Cumhuriyet döneminin tanınmış şairlerinden Behçet Kemal Çağlar, (ö. 1969) Türk Devrim Ocakları Genel kongresi adına yayınladığı tebliğde şöyle demiştir: “Laik ve Devrimci Türkiye Cumhuriyeti'nin aydın ve bilgin olması gereken bir yetkili memurunun devletimize ve devrimimize karşı bir yabancı ve gerici gazetede yayınlanan böyle bir demeçte bulunması gafletini teessürle karŞılarız. Bu demeç bizi hem devrimci Atatürk çocukları hem de halis mümin Türk çocukları olarak incitmiştir." ${ }^{26}$ Çağların Hayırlıoğlu'nun ismini ve unvanını dahi zikretmek imtina ederek, ondan istihfafı çağrıştıran "memur" olarak zikretmesinin nezaket sınırlarına sığmayacağı ortadadır. "Hayırıoğlu'nun beyanatını her şeyden önce ileri ve aydın Türkiye'mizin inkılaplarına müteveccih bir hareket olarak telakki etmekteyiz" diyen MTTB Genel Sekreteri'nin söyleminin de diğerlerinden farklı olmadığı ortadadır. ${ }^{27}$ Dernek yöneticileri ve bilim adamlarının bu söylemi daha sonra tabana yayılmıştır. Hayırlıoğlu'nun istifasını isteyen İzmirli gençlerin gerekçisi de aynıdır: “Sayın Hayırlıoğlu'nun Diyanet İşleri Reisliğinde tutulması, Atatürk inkılaplarına aykıııdır."28

Hayırlıoğlu'na en sert tepki Mustafa Kemal Derneği'nden gelmiştir. Basına verdiği demeçte diğerleri gibi “Kur'an'ın Tercümesi” ile Latin Kur'an meselesini birbirine karıştıran dernek başkanı Muhtar Kumral ${ }^{29}$ düşünceden çok hakaret içeren demecinde şöyle demektedir: "Hoca Efendi, kendine gel. Beşikten mezara kadar ilim tahsil ediniz." diyen bir peygamberin ümmetiyiz. Kur'an 41 dile tercüme edilmiştir. Bırak Allah aşkına bu saçma fikirleri... Dinimiz bütün dinlerin üstünde en son ve mükemmel dindir. Başka milletlerin fertleri, kendi dillerine çevrilen Kur'an'ı okuyarak akın akın Müslüman oluyorlar. Hoca efendi... Sen o kara bayrak gibi mantıksız fetvan ile mübarek dinimizin kapılarını insanlığa kapayamazsın. Bu suçundan dolayı inan ki, ulu peygamberimiz Hazreti Muhammed Allah katında senden davacı olacaktır. Hoca Efendi! Bu halinle sen, Atatürk Türkiye'sinin Diyanet İşleri başkanı değil, inan ki, bu geri ve mantıksız fetvanla bir köy imamı bile olmazsın. Artık iş başında kalamazsın. Zaten Türk efkârı umumiyesi vazifenden azletti. Hoca, hoca... Bir kere daha Atatürk çocuğu olarak haykırıyorum. Cübbeni topla evine dön. Hiç durma, istifa et, istifa et, isti-

\footnotetext{
${ }^{25}$ Milliyet Gazetesi, 13.10.1958, 3.

${ }^{26}$ Milliyet Gazetesi, 05.01.1958, 1.

27 Cumhuriyet Gazetesi, 08.10.1958, 5.

${ }^{28}$ Cumhuriyet Gazetesi, 05.10.1958, 5.

${ }^{29}$ Cumhuriyet Gazetesi, 15.01.1959, 3.
} 
fa et."30 Milliyet Gazetesi'nin dernek başkanının bu açıklamalarını ifade özgürlüğü sadedinde neşretmediği ortadadır. Zira alenen hakaretler içeren böyle bir demeci yayınlamak basın özgürlüğü ile açıklanabilecek bir tavır değildir. Ayrıca gazetenin “Cübbeni topla evine dön” cümlesinin yanına Hayırlıoğlu'nun nerde çekildiği belli olmayacak şekilde kırpılarak mpntajlanan, cübbeyi andıran paltolu bir fotoğrafını yerleştirmesi bu habere nasıl teşne olunduğunun kanıtı olarak durmaktadır. Dernek başkanının hakaret içeren konuşmasını sansürlemeden veren gazete Hayırlığlu'nun beyanatını ise işine geldiği gibi kırparak vermesi de aynı düşüncenin ürünüdür. ${ }^{31}$

\subsection{Transkripsiyon Alfabesinin Latince Kur'an İçin Yeterli Görülmesi}

Arap harflerine ve Arapçaya toptan karşı çıkan, bütün ibadetlerin Türkçe yapılması gerektiğine inanan ve dinde reform taraftarı olan Osman Nuri Çerman dışında, Latin harflerinin mevcut haliyle Kur'an'ın okunabileceğine kani olan birisine rastlamadık. Kur'an'ın Latin harfleriyle yazılabileceğini düşünenler yeni alfabenin mutlaka gözden geçirilmesi ve bazı ilavelerle yeniden düzenlenmesi gerektiğini dile getirmişlerdir.

İlahiyat Fakültesi Din Psikolojisi ve Pedagoji profesörü Bedii Ziya Egemen'e göre “Kur'an'da ve hadiste başka harflerle Kur'an'ın yazılıp yazılamayacağına dair bir hüküm bulunmamaktadır. Türk alfabesinin Arapça metinleri asıllarındaki telaffuzla yazılıp yazılamayacağı meselesi tartışılabilir. Türk alfabesi bazı transkiripsiyon işaretleriyle en ağır klasik metinleri ifade etmek kudretindedir."32 Ankara Müftüsü Sadık Başöz de aynı görüşte olduğunu ifade etmiştir. ${ }^{33}$

Kur'an'ın Latin harfleriyle gayet güzel yazılacağını iddia eden Profesör Mükrimin Halil, Latin, Arap harfi diye bir şey olmadığını, hepsinin Fenike asıllı olduğunu söylemiş, lakin harflerimizin kâfi olmadığını, takviye edilmesi gerektiğini belirtmiş ve hemen herkes gibi oda işi tercümeye getirip "Şarkın kalkınması bakımından Mukaddes kitabın tercümesi zaruridir." demiştir. ${ }^{34}$ Mükrimin Halil'le beraber Hür Fikirleri Yayma Cemiyeti'nin, Kur'an'ın Latince yazılıp yazılmayacağı konusunda tertip ettiği münazaraya katılan Abdulkadir Karahan ise demecinde Kur'an tercümesini öne çıkarmıştır: “Kur'an-ı Kerim Çince Finceye da-

\footnotetext{
30 Milliyet Gazetesi, 06.10.1958, 1.

31 Milliyet Gazetesi, 07.10. 1958, 1

32 Cumhuriyet Gazetesi, 5.10.1958, 5.

${ }^{33}$ Cumhuriyet Gazetesi, 5.10.1958, 1958, 5.

34 Milliyet Gazetesi, 29.11.1958, 3.
} 
hi tercüme edilir. Ancak bir ilmi heyet tarafından hazırlanmalı ve ticari meta haline getirilmemelidir. Kur'an'ın yalnız Arap harfleriyle yazılacağına dair bir kayıt yoktur." Milliyet'in haberine göre münazaraya katılmayan İsmail Hakkı Baltacıoğlu ile Prof. Abdulbaki Gölpınarlı da aynı kanaatte olduklarını bildirmişlerdir. ${ }^{35}$

Hür Fikirleri Yayma Cemiyeti'nin düzenlediği bu münazaranın derneğin ismi ile çeliştiği söylenebilir. Gazete haberinden anlaşıldığı kadarıyla münazaraya katılanların -görüşlerini sonradan bildirenler dâhil- tamamı, Latince Kur'an'a taraftardır. Aksini savunanlara münazara da söz verilmemiş görünmektedir. Tek muhalif ses, gazetenin zaman zaman ilim adamlarıyla dini münakaşalarda bulunduğunu haber verdiği, Abdullah Hoca adında birisidir. Fakat o kişinin görüşlerine bir cümle ile olsun yer verilmemiştir. ${ }^{36}$

\subsection{Latince Kur'an'a karşı çıkanların gerekçeleri}

Latince Kur'an'a muhalefet edenler öncelikle kendileri gibi düşünmeyenlerin iddialarına yer vermişler, ardından kendi düşüncelerini açıklamaya gayret etmişlerdir.

\subsection{Latince Kur'an isteyenler samimi olmadıkları}

1950'li yıllardan geriye doğru uzunca bir süre dine karşı gösterilen menfi tutumlar halk nezdinde karşılık bulamadığından, dindar olmayan bazı kesimlerde de din ve mukaddesata karşı hala hissedilir derecede bir saygı söz konusudur. Bu yüzden Latince Kur'an'a taraftar olanlar bu tercihleriyle İslamiyet'e hizmet etmeyi istediklerini özellikle belirtmek istemişlerdir. Latince Kur'an'a karşı olanlar ise muarızlarını hem Kur'an'a ve İslamiyet'e hizmet konusunda, hem de Atatürk ve inkılaplar noktasında samimiyetsizlikle suçlamış, bu düşüncelerini doğrulayacak pratiklerden mahrum olduklarını iddia etmişlerdir.

Avukatık mesleğini icra etmekte olan Ziya Nur, Latince Kur'an taraftarı olan basın organlarını basım sayısını artırma hesaplarıyla suçlamakta, uyguladıkları yayın politikalarının kendilerini ele verdiğini söylemektedir: "Gazeteler açtıkları kampanyada zahirde Kur'an'ın geniş kitle rafından öğrenilmesini hedef tutmaktadırlar. Böyle bir maksat için sayfalarını Kur'an'ın talimine ayırmaları icap ederdi." 37

Dönemin İstanbul Müftüsü A. Fikri Yavuz, Latince Kur'an taleplerinin “ís-

\footnotetext{
35 Milliyet Gazetesi, 29.11.1958, 3.

${ }^{36}$ Milliyet Gazetesi, 29.11.1958, 3.

37 Nur, "Gayeli Taarruz", 53.
} 
lam'ın şartlarını dahi bilmeyen ve feraiz-i İslamiye'den bir tekini dahi olsa yerine getirmeyen nasipsizler ağzından sudur ettiğini" iddia etmiştir. ${ }^{38}$ Çapa Yüksek Öğretmen Okulu Din Bilgisi Öğretmeni Abdurrahman Şeref Güzelyazıcı'nın açıklamaları da bu iddiaları destekler mahiyettedir: "Bu davayı öne sürenlerin ve hücumlu bir üslup ile savunanların Kur'an ve icaplarıyla alakalı bulunmadıkları göz önünde tutulursa hayırsızlığın büsbütün gerçekleştiği görülür."39

Latince Kur'an'ı savunanlar görüşleri arasında bol bol “Atatürk çocuğu, devrim, inkılaplar, mürteci” gibi ifadeleri yerleştirmişlerdir. Açıklamalarını bu ifadelerle süsleyerek kendi düşüncelerine karşı çıkanları Atatürk ve inkılaplara da karşı çıkmış gibi göstermeye çalışmışlardır. Bu yüzden Latince Kur'an'a karŞı çıkanlar da "Ben ne yobazım, ne de inkılap yobazıyım. Türkiye Cumhuriyetinde yetişmiş bir Türk ve Müslümanım" gibi açıklamalar yapmak durumunda kalmışlar, onların düşünlerini yine onların delilleriyle çürütmeye çalışmışlardır. ${ }^{40}$

Böyle münakaşalara karışan veya onu körükleyenlerin Türk milletinin hayrına çalışmadığını belirten Abdurrahman Şeref Güzelyazıcı onları "Cumhuriyet inkılaplarını, fikir hürriyetine, düşünce izharına aman veremeyecek kadar fani ve kanaat dinlemez hale koymak, bu inkılapları anlamak ve ona hürmet manasında değildir." 41 sözleriyle eleştirmiştir. 1500 Müslüman demokrat adına Atatürk Derneği Başkanlığı'na bir telgraf yazan Mehmet Delibaş adındaki vatandaş, Atatürk konusunda samimi iseler, onları Fransızlar tarafından çıkarılan Büyük Ansiklopedi'de Atatürk'e yapılan yersiz isnatlara cevap vermeye davet etmiştir. ${ }^{42}$

Hasan Basri Çantay üç dört sene evvel İstanbul'un bir ilim merkezinde konferans veren bir müsteşrikin vahyi, Kur'an'ı, Peygamber'i inkâr ve alenen tezyif ve tahkir ettiğini ve bir papazın "Nurlu Ufuklar” adlı paçavrasıyla aynı küfriyatı yaptığını, o zaman bir kılı bile harekete gelmeyenlerin şimdi Latince Kur'an talebiyle Kur'an aşığı görünmelerinin inandırıcı olmadığını söyler. ${ }^{43}$

Hayırlıoğlu da yapmış olduğu basın toplantısında bu samimiyeti sorgula-

\footnotetext{
38 A. Fikri Yavuz, “Kur'an-ı Kerim'e Hürmet” Türkçe Kur'an Okunamaz, Haz. Mü’min Çevik, (İstanbul: Sinan Matbaası, 1958), 42.

39 Abdurrahman Şeref Güzelyazıcı, “Türkçe Kur’an ve Basın Müftüleri” Türkçe Kur'an Okunamaz, Haz. Mü'min Çevik, (İstanbul: Sinan Matbaası, 1958), 23.

40 H. Fikri Aksoy, “Kur'an-ı Kerim Nasıl Yazılmış ve Nasıl Yazılmalıdır?” Türkçe Kur’an Okunamaz, Haz. Mü'min Çevik, (İstanbul: Sinan Matbaası, 1958), 32-33.

41 Güzelyazıcı, “Tükçe Kur'an ve Basın Müftüleri”, 23.

42 Sebilürreşad, 12/ 279 (Kasım 1959), 57.

43 Hasan Basri Çantay, “Gayretleri Hüsrandır” Türkçe Kur'an Okunamaz, Haz. Mü’min Çevik, (İstanbul: Sinan Matbaası, 1958), 16.
} 
mıştır. “Kur'an-ı Kerim'in yeni harflerle yazıımasını caiz görmediğim için bana reislikten çekil diyenler, bununla Kur'an'a bağılıklarını mı ispat etmiş oluyorlar?"44 Atilhan'ın şu sözleri Hayırlıŏlu'nu teyit eden bir cevap niteliğindedir “Gariptir ki, bunu bir inkılap meselesi yaparak inkılapları soysuzlaştırmak isteyenlerin bu mevzuda zerre kadar bilgileri ve ilgileri yoktur. Kur'an-ı Kerim'i hangi harflerle yazarsak yazalım bu adamların okumayacakları ve müddeti hayatlarında Zat-ı Kibriya'ya has bir talâkat ve belagatin mucizelerini taşıyan Kur'an-ı Hakîmi bir defa ellerine alıp onun ilâhî zevkine varamayacakları malum ve muhakkaktır. ${ }^{45}$

H. Fikri Aksoy bu konuda, muhaliflerine karşı epey ilginç sayılabilecek şöyle bir yorum geliştirmiştir. "Bu gün 29 adet Türk harflerimizle bu iş olur diye kimse bir iddia yapmıyor. Illle de ilave yapalım harf ve şekil icad edelim de öyle okuyaIım diyorlar. Böyle bir hareket bir inkılapla ve kanunla yapılmış Türk harflerinin adedini çoğaltma şekillerini değiştirmesi bakımından kanuna ve harf inkılabımıza acaba aykırı olmaz mı?" 46 Devamında Arap alfabesinin hiç de zor olmadığını savunan Aksoy, Türklerin, azimli ve kudretli olduğunu, isterse dinin temel taşı, ecdadının baş tacı olan kitabı, Kur'an'ını da yeni metotlarla basılmış Arapça alfabelerle kendi kendine öğrenebileceğini söyler. ${ }^{47}$

Latince Kur'an taraftarları ise Hayırlığlu'nu samimiyetsizlikle suçlamışlardır. Havadis gazetesinde çıkan bir başyazıda Diyanet İşleri Reisinin ortaokullarda tedris edilen din dersleri kitabında yazılı surelerin Türk alfabesiyle yazıımasına ses çıkarmamasını eleştirilmiştir. ${ }^{1}$

Ancak Hayırlığlu'nun kendi hizmet alanına giren bir konuda verdiği fetvaya tahammülü olmayanların, onun ders kitaplarına müdahalesi karşısında şimdikinden çok daha fazla yaygara kopartacaklarını tahmin etmek güç değildir.

Bütün tartışmalar bir yana bırakılarak söylenebilir ki tartışmanın gerçekleştiği dönemde yasalar karşısında Kur'an'ın Latince yazılmasına mani bir durum söz konusu değildir. Latince harflerle Kur'an'ın yazılabileceğini iddia ve bu konuda ısrar edenlerin bu düşüncelerini tatbik etmelerine mani bir durum söz konusu değildir. Hayırlıoğlu yaptığı basın açıklamasında “Latin harfleriyle Kur'an-ı

\footnotetext{
44 “Diyanet Reisinin Beyanatı” Sebilürreşad, 12/279 (Kasım 1959): 52.

45 Cevat Rifat Atilhan, "Kur'an Aleyhinde beynelmilel Komonizm Suikasdı" Sebilürreşad, 12/279, (Kasım 1959): 54

46 Aksoy, "Kur'an-ı Kerim Nasıl Yazılmıș ve Nasıl Yazılmalıdır?", 32-33.

47 Aksoy, “Kur’an-ı Kerim Nasıl Yazılmış ve Nasıl Yazılmalıdır?”, 32.
} 
Kerim'i okumada ısrar edenler, yanlış okumayı peşinen kabul etmiş olmak koşuluyla piyasada mevcut olan Latin Harfli Kur'an-ı Kerim'leri okumakta özgürdürler." diyerek bir bakıma tartışmaya son noktayı koymuştur.

\subsection{Kur'an'ı doğru okumak için transkripsiyon alfabesinin yeterli olmaya-} cağı

Latin alfabesine ilave edilecek bazı şekillerle Kur'an'ın doğru okunabileceğine kani olanlara karşı pek çok makale kaleme alınmıştır. Hayırlığlu'nun fetvasını yerinde bulan bu makale sahipleri konuyu çeşitli yönleriyle tartışmış, düşüncelerini destekleyen örneklerle transkripsiyon alfabesinin güçlüklerini, Arap alfabesi ile öğrenmenin kolaylığını açıklamışlardır.

Latince alfabenin Türkçeyi bile ifadeye kâfi olmadığını söyleyen İsmail Hami Danişmend, bütün dünyada imlası olmayan yegâne dilin Türkçe olduğunu söyler. Ona göre “Kur’an- Kerimin Latin, Çin Yunan veya yeryüzünde kullanılan herhangi bir yazı sistemi ile neşrinde dinen hiçbir mani yoktur. Ancak büsbütün ayrı bir ses sitemine dayanan Arapçayı Latin alfabesiyle ifade etmek mümkün değildir. Mevcut alfabeyle Kur'an neşri imkânsızdır."48 Cumhuriyet döneminin en önemli tarihçilerinden olan Danişmend'in bu görüşü başkaları tarafından da paylaşılmıştır. Çantay, Latin alfabesinin Türkçe kelimeleri yazmaya elverişli olduğu halde, Arapça ve Farsçadan dilimize geçmiş kelimeleri yazmaya elverişli olmadığını söyler. 49

Düşüncelerini iki alfabenin kullandıkları sesli ve sessiz harflerin sayısı ve ses bünyesi üzerinden temellendirmeye çalışan Danişmend son derece geliştirilmiş bir transkripsiyon alfabesinin dahi çözüm olmayacağını belirtir. Çünkü müsteşriklerin geliştirdikleri bu alfabe telaffuzu değil, yalnızca kelimelerin imlasını tespite imkân tanımaktadır. Hâlbuki Arapların imlası ile telaffuzu arasında çok büyük farklar vardır. Mesela imlada "el-Rahman” yazılır, fakat "er-Rahman" okunur. Müsteşriklerin imlasında bir tahrif söz konusudur. Bütün bu olumsuzlukları gidermek için ortaya konacak bir alfabe ise kullanılmakta olan alfabeden bambaşka bir şey ortaya çıkaracaktır. Danişmend, bu işin peşine düşmenin beyhudeliğini şu misalle belirterek sözlerini tamamlar: “Shakespeare'inin Ingilizce bir eserini Arap harfleriyle neşretmek için yeni bir Arap alfabesi icat

\footnotetext{
48 İsmail Hami Danişmend, “Kur'an ve Latin Harfleri” Sebilürreşad, 12/ 279 (Kasım 1959) : 52-53. 49 Çantay, "Gayretleri Hüsrandır”, 15-16.
} 
etmek ne demekse bu da öyle bir şey demektir." 50 Çantay'a göre de yeni harfler, müsteşriklerin transkripsiyon alfabesi olarak ortaya koydukları işaretler de imlada hiçbir çözüm getirmemiştir. Bu imlaya göre Ebu Bekir, Abubakır; Abdülkerim, Abdal Kerim şeklini almaktadır ki bu uygulamayı yaygıılaştırmak bir cinayettir. 51

Sebilürreşad 279.sayısında Fransız bir müsteşrik iken Müslüman olan Nasirüddin Etienne Dinet adı bilim adamının bu olaylardan 30 yı önce kaleme aldığı Librarie Hachette adlı eserinden konu il ilgili kısa bir tercümeye yer vermiştir. Yazıda Arap ve Latin alfabelerini tarih, estetik ve kolaylık açısından karşılaştıran Dinet, tercihini Arapçadan yana yaptıktan sonra şöyle bir benzetme yapar: “Hakikatte Arapçayı yazmak için Latin harflerinin Arap harflerinin yerine ikame etmek istemek, Latinceyi yazmak için Arap harflerinin istimalini istemek kadar manasız ve abestir. ${ }^{52}$

Kur'an'ın Latince alfabeyle okunmasına engel olan hususlar arasında kıraatler ve bazı tecvit kuralları da zikredilmiştir. Çünkü Kur'an'daki bazı kelimeler durulduğunda (vakf) farklı okumaya devam edildiğinde (vasl) farklı okunmaktadır. Bunlar transkripsiyon alfabesiyle çözümlenemez. Kıraatler konusu da Latince Kur'an'a itiraz gerekçeleri arasında zikredilmiştir. Mushaf yazısında yazıldığı halde okunmayan, okunduğu halde yazılmayan bazın harflerin varlığı da bu gruba dâhil edilmiştir. ${ }^{53}$

Her şeye rağmen Latince Kur'an meselesi -Arapça bilmeyen Müslümanların Kur'an'ı kolayca okuyabilmelerini temin gibi- iyi niyetlerle gündeme getirilmiş olsa bile iyice düşünüldüğünde bu arzunun mükemmel bir şekilde gerçekleşebilmesinin de yine Kur'an'ın resm-i hattını muhafazasıyla mümkün olabileceğini belirten Bilmen, on, on beş yaşındaki binlerce Müslüman çocuğun Kur'an'ı tamamen ezberden okuyabilmelerini bu iddiaya delil olarak gösterir. Kaldı ki Latince Kur'an ile insanlar sadece Kur'an'ı okuyabilecekken, Arapça hattı ile okumayı bilenler, sair evrad ve ezkarı da okuyabileceklerdir. ${ }^{54}$

Kaldı ki transkripsiyondan faydalanan garplılar hiç bir zaman asli metinleri

\footnotetext{
50 Danişmend, İsmail Hami, “Kur’an ve Latin Harfleri”, 52-53

51 Cantay, "Gayretleri Hüsrandır", 15-16.

52 Nasirüddin Etienne Dinet, “Sözde İImi İslam Düşmanlığı”, Sebilürreşad, 12/ 279 (Kasım 1959): 63.

53 Aksoy, “Kur’an-ı Kerim Nasıl Yazılmış ve Nasıl Yazılmalıdı?”, 31.

54 Ömer Nasuhi Bilmen, “Kur'an-ı Kerim'in Resm-i Hattını Tağyir Caiz Değildir.” Türkçe Kur’an Okunamaz, Haz. Mü’min Çevik, (İstanbul: Sinan Matbaası, 1958), 13.
} 
terk etmemişler belki metne alıştırma için yardımcı olarak kullanmışlardır. Nitekim bu gün Avrupa matbaalarında Arap alfabesiyle binlerce metin ve eser basılmakta, buna mukabil, yalnız kendi harfleriyle Arapça eser basılmamaktadır. ${ }^{55}$

\subsection{Kur'an-ı Kerim'in resm-i hattını değiştirmenin caiz görülmemesi}

Hayırlıŏlu'nun halefi olan Ömer Nasuhi Bilmen, beklendiği gibi meseleyi dini boyutu ile ele almıştır. Tartışmaların cereyan ettiği dönemde İstanbul Müftüsü olan Bilmen fıkhi açıdan meseleyi enine boyuna tartışmıştır. İbn Hacer elMekkî, Zemehşerî, İbn Dersteveyh gibi âlimlerin görüşlerini naklederek Arapça dışında bir hatla Kur'an-ı Kerim'in yazılamayacağını tasrih etmiştir. Konu ile ilgili fetvalara da yer veren Bilmen, Ezher Ulemasının Boşluk dergisinde yayınlanan fetvasına da yazısında yer vermiştir: "İslam âlimleri selefen ve halefen icma etmişlerdir ki, Kur'an-ı Kerim'de lafzın tahrifine veya mananın tağyirine müeddi olacak herhangi bir tasarruf, kat'i surette memnu; tahrim-i kat'i ile haramdır. Gerek ashab-ı kiram ve gerek onlardan sonra zamanımıza kadar gelen ehl-i i̇slam Kur'an'ın Arabî harfler ile yazıımasını iltizam etmişırlerdir. Bundan da tebeyyün eder ki, Kur'an-ı Azim'in Latin Harfleriyle kitabeti caiz değildir."56

Konuya dini hassasiyetle yaklaşanlardan biri de Güzelyazıcı'dır. Ona göre, Vahiy kâtiplerinin yazısı Hz. Peygamberin takdirine mazhar olduğundan fiili bir sünnet, dolayısıyla şer'i bir delildir. Hz. Peygamber'in vefatından sonra cemediIen Mushaf, ashab-ı kiram tarafından tetkik edilmiş, üzerinde ittifak sağlanmıştır. Günümüze kadar gelen ittifaklarla bu konuda icma sağlanmıştır. Bu şer’i delile hücum, dini inkâr mahiyetinde küfürdür.“57 Yazıcıoğlu ancak yeni Müslüman olmuş bir yabancıya, muvakkat bir zaman için ibadet yapılmasını sağlamak amacıyla, herhangi bir harf ile lüzumu kadar yazmasına cevaz verilebileceğini belirtmiştir." 58 Ona göre Arapça alfabe dışında yazılan Kur'anların asıllarıyla irtibatsızı̆̆ı, zaman geçtikçe tahrif ve tağyire yol açacaktır: “Arap Kur'an'ı, Acem Kur'an'ı, Arnavut Kur'an'ı, Çerkez Kur'an'ı, Türk Kur'an'ı gibi tabirlerin caiz olmadığı ve dil, yazı harfleriyle Kur'an'ın büsbütün tahrife uğraması, tehlikesi taşıdığı unutulmamalıdır. Ehl-i Kitab'ın Tevrat ve İncil'i kaybetmelerine sebep: Li-

\footnotetext{
55 Yavuz, “Kur'an-ı Kerim'e Hürmet”, 44.

56 Bilmen, “Kur'an-ı Kerim'in Resm-i Hattını Tağyir Caiz değildir”, 10-14.

57 Güzelyazıcı, “Türkçe Kur'an ve Basın Müftüleri”, 24-25.

58 Güzelyazıcı, “Türkçe Kur'an ve Basın Müftüleri”, 26.
} 
san, tercüme, yazı farkları olduğu tarihi bir hakikattir."59

\subsection{Latince Kur'an meselesinin siyasi boyutu}

Latince Kur'an'a karşı çıkanlar, bu tartışmaların masumane bir talepten neşet ettiğine inanmamaktadırlar. Onlara göre bu çalışmalar "beynelmilel gizli cemiyetlerin sıkı kontrolü altında bulunan din aleyhtarı bazı gazete sahiplerinin işi mugalata vasıtası yaparak halkın dini hislerini teşvişe vermek ve tirajını artırmaya yöneliktir."60 Cevat Rifat Atilhan kaleme aldığı bir makalede Türkiye'de başlatılan bu tartışmaların Rusya'da Kur'an üzerinde oynanan oyunlarla aynı zamana denk gelmesini çok manidar bulur. Ona göre bu zamanlama, bu işlerin şekli ve sahneye konuşu ne suretle olursa olsun bir merkezden idare edilir gibi hep aynı zamana isabet etmektedir. Bu paralellik dikkatten kaçmamaktadır. ${ }^{61}$

Batı Trakyalı Muharrir Ahmet Aydınlı, "Hadiselerin İçyüzü” adlı makalesinde hadisenin zamanlamasına dikkat çekerek özellikle İmam Hatip Okulunun açıdığı bir günde konu ile ilgili yaygaranın koparılmasını tesadüfi olmadığını iddia etmiştir. Ona göre bu zamanlamanın gayesi "fevkelade tehlike mevcutmuş gibi İmam Hatip Okulunun açılışına mânialar indas etmek ve tedrisat-ı İslamiyeyi durdurmak hatta ilga etmektir. Bu hengâmede Diyanet iş̧leri Reisi Hayırlıoğlu'nu istifaya mecbur etmek ve yerine Farmasono Reformistlerden birini tayin etmektir."62

Milliyet Gazetesi'nin 05 Ekim 1958 tarihli nüshası Ahmet Aydınlı'yı haklı çıkarmaktadır. Gazete Fethiye İmam Hatip Okulunun açılış töreni ile İstanbul İlahiyat Enstitüsünün açılacağını belirten haberi yan yana vermiş, ancak haberlerde ilgili okullardan söz edileceğine Hayırıoğlu'na sataşma tercih edilmiştir. Başbakan Adnan Menderes'in beden dilinden büyük bir anlam (!) çıkartan Milliyet Gazetesi, açılış töreninde Hayırlıoğlu tarafından karşılanan Menderes'in mutadı hilafına bu defa onun elini öpmemesi, sadece tokalaşmakla yetinmesinden aralarının açık olduğu sonucunu çıkarmıştır. Aynı sayfada yan yana verilen iki haberde de “Başvekil, Diyanet iş̧leri Reisi Eyüp Sabri Hayırlıoğlu'nun mutat hilafına elini öpmemiş sıkmıştır." cümlesine tekrar edilerek yer verilmesinin habercilik ilkeleri açısından uygun olmadığı, bunun bilgilendirme kaygısını aşan

\footnotetext{
59 Güzelyazıcı, “Türkçe Kur’an ve Basın Müftüleri”, 26.

60 “Latincilerin Kur'an'a müthiş darbesi” Sebilürreşad, 12/280 (Kasım 1959): 67-68.

${ }^{61}$ Atilhan, "Kur'an Aleyhinde Beynelmilel Komonizm Suikasdı”, 54.

62 Ahmet Aydınlı, “Hadiselerin İçüzü” Türkçe Kur'an Okunamaz, Haz. Mü’min Çevik, (İstanbul: Sinan Matbaası, 1958), 38.
} 
amaçlar taşıdığı ortadadır.63 Başbakan tarafından gerçekleştirilen bir okul açılışına dair haberin manşeti "Hayırlığlu basına kulaklarını tıkadı" şeklinde yazılıyorsa bir yerlere mesaj verilmesi istendiği ortadadır. Cumhuriyet gazetesinde aynı gün çıkan haberde söz konusu törende Başbakan Menderes'in okuldan ayrıırken Hayırlığlu ile vedalaşmadığı özellikle belirtilmiştir. ${ }^{64}$

Ziya Nur, asıl hedefin hükümet olduğunu, muhaliflerin Latince Kur'an meselesini bahane ederek, Hayırlığlu üzerinden hükümete zarar vermeye çalıştıkIarını ileri sürmektedir: "Hadise Diyanet İşleri Reisini istifa ettirebilir. Fakat bizce Sayın Hayırlığlu'nun istifa etmemesi lazımdır. Hayırlıŏlu, hükûmet kendisini azledinceye kadar makamında kalmalıdır. Hükumetin azli din mevzuuna bir baskı manzarası verebilir. Bu halk psikolojisindeki DP prestijini sarsabilecektir. Hadisede politik bir tatbik müşahede edilebilmektedir."65

Ali Fuad Başgil, “onlar” diye nitelediği Latince Kur’an taraftarlarını, hakaret, tahrik, iftira ettikleri, etrafa terör saçtıkları, sütunlarında ağız dolusu laflar ettikleri, masum gençleri kışkırtıp 31 Mart faciasını tekrar yaşattıkları için sert bir şekilde eleştirdikten sonra konunun ekonomik boyutuna dikkat çeker. Ona göre son zamanlarda satışları çok düşen gazetelerin tirajı bu sayede artmıştır. Daha öncede moskof geliyor, irtica var, inkılap elden gidiyor diye aynı yaygarayı koparıp tirajını artırmışlardı. Yarın da keçinin sakalı uzadı diye yine bağıracaklar, gazete satacak, para kazanacaklar.66

Hadiseye farklı bakış açılarıyla bakmak, birbirine yüz seksen derece zıt sonuçlara ulaşmakla neticelenmiştir. Hayırlığlu'nun istifasını isteyen İzmirli gençlerin Sayın Hayırlıoğlu'nun Diyanet İşleri Reisliğinde tutulmasını Atatürk İnkılaplarına aykıı bulurken67 İzzet Neşe adındaki şahıs, Mustafa Kemal Derneği başkanının Atatürk'ü istismar ederek Hayırlıoğlu'na saldırdığını, derneğin bu isim altında faaliyet yürütmesine engel olunması gerektiğini, aksi halde söz konusu şahsın yarın başvekile de dil uzatma cüretini bulacağını ileri sürmüştür. ${ }^{68}$

Yine Milliyet Gazetesi'ne göre Hayırlıoğlu, Batı Trakya'da müretcilerle (!) devrimciler arasındaki bu ezeli rekabette dengelerin bozulmasına sebep ol-

\footnotetext{
${ }^{63}$ Milliyet Gazetesi, 05.10.1958, 1.

${ }^{64}$ Cumhuriyet Gazetesi, 5.10.1958, 5.

65 Nur, "Gayeli Taarruz", 51

66 Ali Fuat Başgil, “Bizim de diyeceklerimiz var dostlar” Türkçe Kur’an Okunamaz, Haz. Mü’min Çevik, (Istanbul: Sinan Matbaası, 1958), 18-19

67 Cumhuriyet Gazetesi, 05.10.1958, 5.

68 İzzet Neşe, “Dini Münakaşalar”, Türkçe Kur’an Okunamaz, Haz. Mü’min Çevik, (İstanbul: Sinan Matbaası, 1958), 54.
} 
muştur. Diyanet İşleri Reis'inin inkılapçı grubun tezini bir çırpıda itmesi, öbür gruba hak vermesi, sessiz mücadeleyi çok vahim bir duruma sokmuştur."69 Ahmet Aydınlı ise bu mektup sayesinde Müslümanların vahdetinin sağlandığını asıl bölünmenin, aksi istikamette bir fetvanın verilmesi halinde yaşayacağını iddia etmektedir. "Bütün bu plan ve projeler E.S. Hayırlıoğlu'nun isabetli ve müstakar mektubu sayesinde akim kalmıştır. Eğer (Farmasono Reformist)lerin fikrine muvafık bir ifade istihsal edilmiş olsaydı, 1958 de binlerce Müslüman Türk camiası muhtelif kavmiyet kategorilerine ayrılmış olacaktı. Balkanlarda yaşayan milyonlarca Müslüman Türk bugün milli benliklerini muhafaza ediyorlarsa bunu Kur'an- Kerim'i asli lisanı ile okumalarına borçludurlar."70

Görüldüğü gibi tartışmalar uç noktalarda cereyan etmiş, tarafların birbirlerini anlayacakları bir zeminde hareket imkânı yakalanamamıştır.

\subsection{Latince Kur'an Taraftarlarının Kur'an'ın Tercümesi ile Kur'an'ın Latin Harfleriyle Yazılmasını Birbirine Karıştırması}

Latince Kur'an taraftarları bu uygulamayla temin edilecek bir takım faydalardan söz etseler de bu faydaların Latince Kur'an'la değil; ancak Kur'an'ın düzgün bir tercümesi ile sağlanabileceği görülmektedir. Bu konuda görüş beyan edenler farkına varmadan Kur'an'ın tercümesinden hâsıl olabilecek faydaIarı Latince Kur'an'a mal etmeye çalışmışlardır.

İlahiyat Fakültesi profesörü, Egemen, İslam'ın üniversal bir din olduğunu, bu yüzden Kur'an-ı Kerim'in bütün dünya dillerine tercüme edilmesi gerektiğini söyler. Ardından Latince Kur'an'la, Kur'an'ın tercümesini aynı kefeye koyarak şöyle der: “Dinlerin en mütekâmili olan İslamiyet'in mahalli dillerle okunup anIaşılmasını sağlamak her Müslüman dindarın borcudur."71 Ankara Müftüsü Sadık Başgöz de konu ile ilgili görüşü sorulduğunda Kur'an'ın 41 ayrı dile tercüme edildiğini, her gün 6-7 kişinin Kur'an tercümelerini okuyarak hidayete erdiğini söyler. ${ }^{72}$

Dinde reform taraftarı olan ve görüşlerinden dolayı mahkemede yargılanıp beraat eden Osman Nuri Çerman adındaki şahıs bütün ibadetlerin Türkçeleştirilmesi gerektiğini iler sürmüştür. Ona göre Türkçe Kur'an insanları dini açıdan kandırmanın önüne geçecektir. Fakat o da bu demecinde Latin harflerinin ne

\footnotetext{
69 Milliyet Gazetesi, 13.10.1958, 3.

70 Aydınlı, "Hadiselerin İçyüzü", 39.

${ }^{71}$ Cumhuriyet Gazetesi, 05.10.1958, 5.

72 Cumhuriyet Gazetesi, 05.10.1958, 5.
} 
gibi faydalar getireceğinden söz etmemektedir. ${ }^{73}$

Türk Kültür Ocakları Genel Merkezi Başkanı Mualla Anıl da Latince Kur'an isteyenler safında yer almıştır. Latince Kur'an'ı Atatürk hamleleriyle ilişkilendiren Anıl açıklamalarında zaman zaman Latince Kur'an'la Kur'an'ın Türkçe tercümesini karıştırmaktadır. "Anlamadan okuduğumuz kitabımızın surelerinde büyük Allah'ımızın hangi buyruğunu, yap yapma dediğini anlıyoruz? Kendi dili içinde kendi kitabını bilen insan en gerçek yolda yürüyor demek değil midir?"74

İlahiyat Kelam Profesörü Nafiz Danışman, vahyin filan veya falan yazı ile yazıımasının şekilcilikten ibret olduğunu, İslam âlimlerinin özelde de kelamcıların böyle bir konuda konuşmadıklarını söyler. Düşüncelerini genişleterek Latin harflerle Kur'an'ın yazıımasına karşı çıkanların, Kur'an tercümesine de muhtemelen karşı çıkacakları kehanetinde bulunur. ${ }^{75}$

Yapmış olduğumuz araştırmada bu konuda makul hiçbir açıklamaya tesadüf etmediğimizi belirtmek isteriz. Mesela Latince Kur'an'la harflerin daha kolay telaffuz edilebileceği, daha pratik şekilde öğretilebileceği, daha estetik görüneceği veya ulusal ve uluslararası şu veya bu faydaların temin edilebileceğine dair tek bir düşünce dile getirilmemiştir.

Bu durumda geriye tek intimal kalmaktadır ki, o da Latince Kur'an isteyenlerin, taleplerinin karşılanması halinde ortaya çıkacak olumsuzlukları fayda olarak telakki etmeleridir. Zira bu durumda Türkiye'deki Müslümanların diğer i̇slam ülkeleriyle olan en güçlü bağı da ortadan kalmış olacaktı. Ziya Nur'un tespitlerine göre daha tartışmalar devam ederken bile Arap radyoları bu hareketi mevzubahs ederek, Türkiye aleyhinde dış Müslüman dünyasında derin neticeler hâsıl edebilecek neşriyatta bulunmaya başlamışlardır. ${ }^{76}$

\section{Sonuç}

Kur'an-ı Kerim'in Latin harfleriyle yazılıp yazılamayacağı meselesi, 4. Diyanet İşleri Başkanı Eyyüp Sabri Hayırlıoğlu ile basın organları arasında cereyan eden pek çok polemik konusundan birisidir. Tamamen ilim erbabının tartışması gereken bu mesele kısa zamanda siyasi bir boyut kazanmış, kimi basın organIarının olaya karışması ile mesele bütün ülkeye yayılmış, yurt dışında da belli düzeyde etkili olmuştur.

\footnotetext{
${ }_{73}$ Cumhuriyet Gazetesi, 09.10.1958, 5.

${ }^{74}$ Cumhuriyet Gazetesi, 20.10.1958, 1-3.

${ }^{75}$ Cumhuriyet Gazetesi, 5.10.1958, 5.

76 Nur, "Gayeli Taarruz", 51.
} 
Hayırlığlu'nun kendisine yazılan özel bir mektuba cevaben verdiği Latince Kur'an olmayacağına ilişkin fetvasından vazgeçmemesi kimi basın organlarını ve dernekleri rahatsız etmiş, konuyu uzun süre gündemde tutmuşlardır.

Latince Kur'an isteyenlerin konu hakkındaki düşüncelerinin net olmadığı görülmüştür. Latince Kur'an'ın yararları diye ortaya konulan, insanların bu sayede hidayete ereceği, gençlerin okudukları Kur'an'ı anlamaya hakları olduğu gibi gerekçeler, görüleceği üzere Kur'an'ın tercümesinden elde edilecek faydalardandır.

Hayırlıoğlu'na yöneltilen eleştirilerde orta yolu tutup fonetik açıdan Latince alfabenin eksiklerinin giderilmesi halinde Latince harflerle Kur'an yazılabileceğini iddia edenler olduğu gibi, namaz dâhil her türlü ibadetin Türkçe ve bütün yazı alfabesinin de Latince olması gerektiğini söyleyen ve toptan reform taleplerini dillendirenler de olmuştur. Hayırlıoğlu'na yöneltilen eleştiriler zaman zaman konunun sınırlarını aşmış, hakaret boyutuna ulaşmış, bu görüşte olan medya organlarında bu ağır eleştiriler sansürlenmeden haberleştirilmiştir.

Sebilürreşad başta olmak üzere Latince Kur'an olamayacağını ileri sürüp Hayırlıoğlu ile aynı görüşü paylaşanlar da kendi basın organları aracılığı ile olaya müdahil olmuş, Hayırlı oğlu'nu destekleyen yayınlara yer vermişlerdir. Latince Kur'an olamayacağını savunanlar meselenin siyasi olarak ortaya konduğunu, oysa ilmi olarak bakıldığında Kur'an-ı Kerim'in resm-i hattını değiştirmenin caiz olmadığı ve Kur'an'ı doğru okumak için transkripsiyon alfabesinin yeterli olmayacağı hususların rahatlıkla görüleceğini ileri sürmüşlerdir.

Bazı basın organlarının siyasi irade ile Hayırlıoğlu'nun arasını açma gayretleri işe yaramamış, Hayırlıoğlu görevde kaldığı zaman zarfında bu konuda geri adım atmamıştır. Konu Hayırlığlu'nun emekliye ayrılmasıyla kendiliğinden kapanmıştır.

\section{Kaynaklar}

» Aksoy, H. Fikri, “Kur'an-ı Kerim Nasıl Yazılmış ve Nasıl Yazılmalıdır?” Türkçe Kur'an Okunamaz. Haz. Mü'min Çevik, 28-35. İstanbul: Sinan Matbaası, 1958.

» Aydınlı, Ahmet.“Hadiselerin İçyüzü” Türkçe Kur’an Okunamaz. Haz. Mü’min Çevik, 36-41, İstanbul: Sinan Matbaası, 1958.

» Başgil, Ali Fuat,. "Bizim de diyeceklerimiz var dostlar”. Türkçe Kur'an Okunamaz, Haz. Mü'min Çevik, 18-19, İstanbul: Sinan Matbaası, 1958.

» Bilmen, Ömer Nasuhi. “Kur'an-ı Kerim'in Resm-i Hattını Tağyir Caiz Değildir.” Türkçe Kur'an Okunamaz, Haz. Mü'min Çevik, 10-14, İstanbul: Sinan Matbaası, 1958.

" Cevdet [Karlıdağ], Abdullah. “Latin Harfleri Meselesi”. İctihad Dergisi 23/240 (15 Teşrinievvel 1927): 4583-4586

" Cumhuriyet Gazetesi (Dipnotlarda belirtilen tarihli nüshalar)

» Çantay, Hasan Basri.“Gayretleri Hüsrandır” Türkçe Kur’an Okunamaz, Haz. Mü'min Çevik. 
15-17, İstanbul: Sinan Matbaası, 1958.

» Dinet, Nasirüddin Etienne. "Sözde İImi İslam Düşmanlığı", Sebilürreşad, 12/. 279, (Kasım 1959) 61-63.

» Ertan, Veli. “Sâbık Diyanet İşleri Başkanı Eyüp Sabri Hayırıığlu (1884-1960)”. Diyanet IIImi Dergi [Diyanet Iş̧leri Başkanlığı Dergisi], 7/77 (Ekim1968): 227-228

» Eşref Edib, “Latin Hurufatı Aleyhinde Mühim Bir Rapor”. Sebilü'r-Reşad 25/627 (27 Teşrin-i Sani 1340): 45.

» Güzelyazıcı, Abdurrahman Şeref. “Türkçe Kur'an ve Basın Müftüleri”. Türkçe Kur'an Okunamaz. Haz. Mü'min Çevik, 22-27, İstanbul: Sinan Matbaası, 1958.

» Milliyet Gazetesi, (Dipnotlarda belirtilen tarihli nüshalar)

» Neşe, İzzet. “Dini Münakaşalar”. Türkçe Kur'an Okunamaz. Haz. Mü'min Çevik. 54-55, i̇stanbul: Sinan Matbaası, 1958.

» Nur, Ziya. “Gayeli Taarruz”. Türkçe Kur'an Okunamaz. Haz. Mü’min Çevik, 49-53, İstanbul: Sinan Matbaası, 1958

» Yavuz, A. Fikri. “Kur'an-ı Kerim'e Hürmet” Türkçe Kur’an Okunamaz. Haz. Mü'min Çevik. 42-44, İstanbul: Sinan Matbaası, 1958. 